\title{
What makes us human? Augustine on interiority, exteriority and the self
}

\section{JOHN ANTHONY BERRY}

University of Malta, Malta

john.berry@um.edu.mt

\begin{abstract}
The composition of the human person is a central issue for Augustine. He addresses it in a philosophico-theological way; particularly in The Soliloquies and in The Confessions. What is at stake here is his exposition of "what" constitutes a person's being human. This paper refers to some of his key ideas in this regard and attempts to identify and establish what this great thinker understands by specific terminology: the soul, the mind, and the self. His hunger for knowledge of the self helps his readers to ponder on the shifting emphasis between interiority and exteriority as well as a person's consciousness and selfhood. Augustine wrestles with the concept of the soul, but at no point does he minimise the role of the intellect. After examining four definitions given by Augustine of the human person, this paper attempts to clarify all underpinnings related to this subject, as to be able to answer the topic in question.
\end{abstract}

Keywords: Human; person; interiority; self; body and soul.

This paper seeks to answer the question "What makes us human?” from a philosophico-theological point of view. It claims, in reference to Augustine (354-430) one of the early Christian thinkers, that a person's consciousness and awareness of one's whole in relation to the self (interiority) and others (exteriority), particularly God, is an appropriate answer to this research, at 
least in the Christian tradition. This study starts by analysing how Augustine's principle of interiority sheds lights on humanity as an existential riddle. Secondly, it examines the North African theologian's Socratic and Aristotelian roots in order to establish his understanding of the human person. Lastly, the research presents four definitions of the human person that Augustine gives in relation to self-awareness, participation and immutability.

The principal characteristic of Augustine's philosophy and theology is that only when the whole person turns toward the truth that it becomes available to him or her (Williams 1956, 6). This thought is captured in Augustine's axiom that "unless we believe, we shall never understand" (Augustine, On Christian Doctrine 2,12,17. All references related to articles or books that do not indicate the author are written by Augustine). God's revelation - even though of a mysterious nature - is considered foundational and credible through a much-needed engagement between reason and faith. In Augustine's eyes, faith and reason are not two irreconcilable camps. They are never to be opposed. On the contrary, they are meant to complement each other in the same manner that a person who seeks the truth is not simply a disembodied mind. The complementary dimension between reason and faith takes place in a whole being. One's wholeness (gr. pleroma) - that is one's readiness or ability to think and speak out one's mind as well as to remain silent before the mystery of life - becomes decisive to present an answer to our preliminary question. Wholeness is here understood in terms of one's inner disposition (of one's totality), rather than something measured in time and space.

\section{Interiority as a fundamental principle}

The first step in this research is to understand Augustine's philosophy. This is important since the Christian tradition - through his influence as a Bishop of Hippo and Doctor of the Church - follows early Greek philosophy that emphasises interiority. Augustine's philosophy is centred on the desire to seek the truth that takes place within his own self (Confessions 10,1,1). This is evident in his life experiences marked by a series of intellectual and 
religious conversions. Moreover, Augustine in his writings is manifestly conscientious towards restless individuals adrift in a world that gives them little or no support. He writes: "Is not a human person's heart an abyss? For what abyss is deeper? [...] It is night, because here the human race wanders blindly" (Exposition on Psalm 41,13,9).

Augustine follows other ancient philosophers who examine this theme. The Neo-Platonists, Plotinus in particular, had already developed a whole language of interiority. Augustine discovers interiority as a philosophical principle through his reading of books by Platonist disciples. This is attested in Book VII of The Confessions. These readings are imperative in the sense that they lead him to the path of the return to the self. By this, the North African theologian understands the inner movement as a personal search that enables him to discover one's spirituality. The return to self becomes a logical conviction of the searcher as 'beloved' in the eyes of God. This quest for interiority in fact liberates him from Manichaeism. Augustine narrates this when he says:

And being thence warned to return to myself, I entered into my inward self, Thou leading me on; and I was able to do it, for You had become my helper. And I entered, and with the eye of my soul (such as it was) saw above the same eye of my soul, above my mind, the Unchangeable Light. [...] Not like this was that light, but different, yea, very different from all these. Nor was it above my mind as oil is above water, nor as heaven above earth; but above it was, because it made me, and I below it, because I was made by it. He who knows the Truth knows that Light; and he that knows it knows eternity. Love knows it (Confessions 7,10,16).

Augustine perceives humanity as a riddle, unless related to God. Augustine takes time to understand this and his psychology and personality are not easily grasped in his early writings. This is even more so when he describes himself as "a man who writes as he progresses and who progresses as he writes” (Letter 143). On the topic of interiority in Augustine's thought, one can consult various authors including Paul Henry, Phillip Cary, Gerald O’Daly, Luigi Alici and other renowned Italian Augustinian scholars who 
are also included in the bibliography. The North African theologian seeks to understand his being human not so much through an ideology as to through the search for truth.

Throughout his writings, Augustine presents a "textual self" wherein he does not simply narrate or portray an examination of his life or intellectual conversions, but also his keen interest in the credibility or the meaningfulness of his humanity (in front of others and God). His yearning to reveal the “inner man” becomes the chief object of narration (O’Donnell 2001, 20). This is neatly described in the question "Who Am I, What Am I?" (Confessions $9,1,1)$. Augustine demonstrates his desire to capture and understand the nature of being human. The North African Theologian approaches the issue of human nature from the perspective of existential philosophy. In so doing, his initial way to understand the nature of the human person was an experiential and a practical one. He approaches the theme of humanity with particular tools that include experience, reason and language.

Augustine's attempt to describe the mystery of his being human is characterised by an existential difficulty. In The Confessions, he exclaims profound statements about himself and his humanity: "I have become an enigma to myself" (Confessions 10,33,50). Indeed, what makes a person human? Can human nature be ever explained? Can it be examined in itself (philosophically) or should it be analysed in relation to God? In other words, is the method employed by Augustine in the dialogues similar to that used in the Confessions?

After his conversion to Catholicism, Augustine presents himself in the light of truth as paradox. The more he seeks to understand himself as a person, the more he discovers himself as a "land of famine" (Confessions $2,10,18$ ) and a "great enigma" (Confessions 4,4,9). In his concluding chapters of The Confessions, he speaks of a much-needed re-creation of his very being. One notes in Augustine a certain hesitation to answer problems arising from anthropology. He exclaims: "I know not from where I came into this - shall I call it "dying life," this "living death"? (Confessions 1,6,7). He adds that "I have become for myself a land hard to till and of heavy sweat" (Confessions 10,16,25). 
Augustine explains that an intellectual struggle is necessary to determine the nature of his identity as a human person and his calling as a Christian. Alternatively, but complementarily, in his philosophical dialogues, Augustine emerges as a speechless philosopher filled with awe in front of the mentioned existential preliminary question. For this reason, he seeks to understand the soul and God as well as their relation to one and another. This is evident in his work titled The Soliloquies. Augustine's axiom manifests the only two themes of his philosophy around which all the other things revolve: God and the self. He says: "God, who is always the same, may I know myself, may I know you" (Soliloquies 2,1,1: "Deus semper idem: noverim me, noverim te”).

\section{Augustine's Socratic and Aristotelian Roots}

One sure way to analyse Augustine's understanding of the human person must take place in view of ancient Greek philosophy. Haunted by existential problems and tormented by his passions, Augustine embarked on a quest to discover himself. As evident in Book 10 of The Trinity, he was aware of the famous maxim "know thyself" which both Socrates and the sophists held so dearly. Augustine's quest in The Confessions becomes an attempt to philosophise in an inward manner. His is a philosophy that searches for its Socratic roots (Sanabria 1987, 123).

One of the reasons why Socrates is fundamental to Augustine is his primary interest in the nature of the human person. Augustine was aware that Socrates' philosophical search was neither for a hidden God (since God is the object of faith), nor for the cosmos (since the person who tries to know the cosmos would be attempting to violate the secrets of God). On the contrary, Socrates was interested in knowing the human person. Thus, Augustine follows in the footsteps of the Greek philosophy, but applies an abstract and a historical perspective (Flórez 1952, 265-278; 1954, 551; 1958).

On the one hand, the first perspective presents Augustine as a philosopher who, in adhering to the thought of Neoplatonism, attempts to arrive at an abstract understanding of the human person. He was also influenced by different schools of thought including that of the Stoics, of Varro and 
of Cicero. The Stoics taught that people should be free from passions, to be unmoved by joy or grief. Two celebrated stoics of whom Augustine was familiar to were Marcus Terentius Varro (116 BC - 27 BC), a Roman scholar as well as Marcus Tullius Cicero (106 BC - 43 BC), a Roman philosopher and politician.

On the other hand, the historical perspective presents Augustine as one who examines the human person in the light of the Scriptures and the Christian way of life. An example of the historical understanding of the human person is the biblical reference to the heart. Augustine exclaims, "What is my own heart, after all, but a human heart?" (The Trinity, 4). This perspective is called historical not so much in terms of periods of development, but rather because of one's relationship and openness to God and his love in one's life. In this light, for Augustine the human person emerges as a mystery. He says, "What, then, am I, O my God? Of what nature am I? A life various, and manifold, and exceedingly vast” (Confessions 10,17,26). Thus, whereas the abstract perspective asserts that one can speak of the human person with precision and logic, this is not the case with the historical perspective. Augustine's method of interiority means to contextualise the human person in terms of history or in terms of one's vocation.

Augustine's existential point of departure concerns the transcendence of the human person (towards God) as in distinction to an understanding of him/her in abstract reasoning. According to the Bishop of Hippo, the human person transcends itself because s/he has both an ontological and a historical dimension. For Augustine, the human person - embedded in a past and a future - remains an enigma. He explains that neither the spirit of the human person, nor his or her restlessness can be entirely grasped or understood.

The existential perspective adopted by Augustine in The Confessions is also present in earlier texts such as On Order and the Soliloquies. Here the areas of concern are two: the human person and God (On Order 2,18,47). Augustine explains that knowledge of the human person is acquired through a method of interiority. This does not mean a reduction to subjectivism or solipsism. On the contrary, as Socrates advises, every person comes to 
know him/herself through introversion or interiority (Sanabria, 1987, 123). Augustine's philosophy can be described as a theocentric anthropology, since he is interested in knowing the human person, particularly as God's image.

Augustinian philosophy can be compared to transcendent humanism where the human person lies at the centre of reflection as a person who is capable of transcending him/herself to get to God. José Rubén Sanabria explains that properly speaking, for North African thinker, the human person is not simply a being, but rather a being in relationship (Sanabria 1987, 124). While such an explanation might seem a religious one, it reveals an expression of mystical philosophy of a Stoic and Neoplatonic inspiration (Campelo 1981, 30).

Besides Socrates, Aristotle is another influence on Augustinian thought on human person, particularly with reference to the concept of the soul and its immortality. Augustine wrote the third and final book to the Soliloquies, entitled on The Immortality of the Soul, after returning to Milan in late 386 / early 387 (De Labriolle, 1948, 167). In this dialogue, Augustine is interested in the question of how the soul can remain immutable even though it moves the body. As such, the issue of immutability of the soul is problematic in Augustine in that some hold that Augustine does not perceive the soul as being immutable. Immortality does not entail immutability for Augustine (unlike for Aristotle).

This dialogue rests on two main assumptions: the soul is immortal and the knowledge of the soul serves as a means and a way of attaining knowledge of God. For Augustine, just as truth is immortal, so is the soul. Immortality, Augustine argues, is worthless without knowledge, and knowledge, in turn, brings with it happiness (Ramsey 2000, 12). In the footsteps of the Greek master, Augustine identifies three dimensions of the human person. These are:

1. vita seminalis or the vegetative life,

2. vita sensualis or the sensuous life, and

3. vita intellectualis or the intellectual life (The City of God 5,11).

Augustine explains that the human person, gifted with a soul, is not only a living substance (characterised by vita seminalis and vita sensualis), 
but has also a vivifying principle. The soul represents the life principle of the human person, that is, the source of his/her physical unity, which hinders physical dissolution and regulates the vegetative functions of nutrition, growth and procreation. Augustine confirms this when he says: "The soul, through its presence, gives life to this earthly and mortal body" (On the Christian Struggle 20,22; The City of God 13,12; Bettenson 1956, 522). Roy W. Battenhouse argues that the quality of the union of the soul and the body remains a mystery all his life for Augustine as well as for the philosophers after him. The soul for the North African thinker possesses an identity that in some mysterious sense, experiences time which is but a fleeting and dimensionless present. In the words of Battenhouse, it "can remember the past, promote future ends, retain constancy of purpose, and remain 'the same' soul” (Battenhouse 1956, 110).

The vita intellectualis of the human soul includes three main faculties: memory, intelligence and will. Augustine explains that these are not separated essences, but all three participate in the substantiality of the soul. To Augustine, nothing can separate the rational soul from timeless truth. This idea is later expressed more clearly: "These three, therefore, memory, intelligence, will are not lives, but one life, not three souls, but one soul; and consequently, not three substances, but one substance" (The Trinity 10,11,18). Whatever is immutable is eternal and true according to Augustine. Since truth exists only in reason, he concludes that reason in its highest degree is to be found only where the highest immutability is present, namely, in God.

Augustine explains that the mind can possess wisdom in turning toward the source of its being, and can lose it by turning away from it. He explains that God takes care of the soul, and thus the soul cannot be forced by him to be changed into a body (On the Immortality of the Soul 13,22). Augustine uses one of the arguments which Plato had used to demonstrate the immortality of the soul (De Labriolle 1948, 167). The soul must have a Creator. It communicates to its Creator. The soul cannot admit its opposite, which is death, but rather finds its meaning in God. This leads us to consider four different definitions by which Augustine seeks to understand the human person. 


\section{Augustine's four definitions}

Before considering the Christian philosopher's definitions of the human person, one should consider three diverging positions among scholars in this regard. These naturally explain and justify the plurality of definitions that Augustine included in his writings about the human person.

A first position is that Augustine's anthropology is marked by Platonic dualism throughout all his work until the last published book. In other words, Augustine understands the human person as body and soul in as much as they are conjoint separate entities. Scholars who have studied this line of thought include Prosper Alfaric and Régis Jolivet.

A second position holds that Augustine's definition of the human person is characterised by an evolution of his thought. Supporters of this claim, including Charles Boyer and Jacques De Blic, argue that Augustine was initially Platonic, but ended up presenting a unitary vision. In short, there is a shift in Augustine's understanding that emphasises unity, rather than duality.

The third position emphasises that Augustine's anthropological insights are unitary right from the start. In simple words, the human person is composed of the soul and the body. Authors like Charles Couturier, Michele Federico Sciacca, Agostino Trapè and Nello Cipriani explain that the soul and the body are so profoundly united, that such unity is mysterious (Piccolomini 2002, 281; Fabro 1958, 123).

These three perspectives present us with a sound contextualisation of his four definitions on the human person: first, the unity of the body and the soul; second, a rational, mortal animal; third, a soul that makes use of the body, and fourth, a certain kind of substance, sharing in reason, fitted to rule the body. To be precise, the last should not be considered as a definition of the human person. It is rather a definition of "animus", that is, a definition of the only spiritual element of the human person. Nevertheless, it is useful to refer to it as it helps us understand Augustine's frame of mind (The Magnitude of the Soul 13,22; Gilson, 1936, 174). The research now presents Augustine's four definitions of the human person: 


\section{a) The human person as the unity of the body and soul}

Nello Cipriani in studying the influence of Varro on Augustinian anthropology argues that when Augustine speaks of the supreme good, his mention of the human person refers to the unity of the body and soul. In his analysis of book XIX of The City of God, Cipriani explains that there can be neither the soul without the body, nor the body without a soul. Certainly, a different view would argue that this is not true, since after death, there is the soul without the body (since the soul is immortal). Nevertheless, the soul and the body stand together (Cipriani 1996, 369-400). Augustine rejects the Manichean understanding of the human person and endorses Varro's theory of the prima natura. This refers to the primary goods relative to the body and the soul and to that of virtue, which is the most excellent and good (Piccolomini 2002, 282). In simple words, Augustine re-considered corporeality which the Manicheans unhesitantly condemned and which the Neoplatonists underestimated.

Augustine's reading of Varro is evident in his early writings. In The Morals of the Catholic Church, written in 388 during his second stay in Rome, Augustine addresses the problem of the Supreme Good from the definition of man, composed of body and soul. The problem of the relationship of the soul and the body is treated also in The Measure of the Soul, composed in the same period of The Morals of the Catholic Church. Even in this work, Augustine speaks of the prima naturae, of the bona corporis (Stoics, Varro) and of the triple Aristotelian distinction of the goods: the soul, the body and the social goods (Piccolomini 2002, 282).

\section{b) The human person is a rational, mortal animal}

The second definition that Augustine gives is that the human person is a rational, mortal animal. This is found in his On Order (Divine Providence and the Problem of Evil 2,11,31). The term "rational" is used to distinguish the human person from instinctual animals, while "mortal" is used to distinguish the human person from God. Augustine explains that "unless it holds fast to the rational element, it will be a beast; unless it turns aside from the 
mortal element, it will not be divine" (Divine Providence and the Problem of Evil 2,11,31). In this way, therefore, this definition succinctly expresses the unity of soul and body that make up the human person. Nevertheless, unless one is rational or able to decide for oneself, then one would not be a fully human being. So where as the emphasis of the first definition is on the unity of the body and soul, the second definition emphasised the role of reason.

\section{c) The human person is a soul that makes use of the body}

A third definition that Augustine uses is that the human person is a soul that makes use of the body: "homo anima rationalis est mortali atque terreno utens corpore" (On the Catholic and the Manichean Ways of Life 1,27,52). This reasoning leads Augustinian scholars to claim that there is a clear dualism between the body and the soul. This definition would be totally opposed to that of Varro. There is a difference in the thought of Augustine as exemplified in his On Order written in 386 and in his The Morals of the Catholic Church and On the Morals of the Manicheans written in 388. These two definitions are not mutually exclusive because On Order defines the human person in terms of his specific difference (composed of soul and body), while $O f$ the Morals of the Catholic Church speaks of the human attitude in relation to the Supreme Good (and defining the human person as a soul that makes use of the body). So, while this definition distinguished the body and the soul, in this definition, Augustine seeks to emphasise the primacy of the soul. Somehow, the body is dependent on the soul.

\section{d) A human person is a certain kind of substance, sharing in reason, fitted to rule the body}

As already stated above, although the fourth definition concerns the 'animus', it still sheds light on the human person. Augustine speaks of a certain kind of substance, sharing in reason, fitted to rule the body. From his early works, he explains that of its nature, the soul refers to a relationship to the body. The soul seeks to give life to the body and to possess it. This is certainly different from what Platonism upholds, namely that the body is a negative element 
from which the soul must free itself through a series of reincarnations in order to return, purified, to the One.

There are two contrasting positions that one should be clear about. One holds that the soul is not of divine substance, as was claimed by the Neoplatonists. These hold that both the One and the Intellect are above the soul. The other position holds that the soul has been created by God, is similar to Him and is given to animate the body and govern it. In this sense, the body is different from the soul, but the body is a requisite for the soul to be called a human person. For the sake of clarity, since the doctrine of the divinity of the soul is only a Manichaean doctrine, Augustine believed that the Neoplatonists did not think that the soul was divine (City of God $8,1 ; 8,5 ; 8,6)$. Nonetheless, on the relationship of the soul to the body, the North African thinker says:

"Who can reasonably offer any complaint because the soul was given to move and manage the body, since an order of things so great and so divine could not be better linked together?" (The Magnitude of the Soul 36,81).

If the soul is meant to be in close relationship to the body, then the body cannot be considered as a prison of the soul (Plotinus, Treatise 1.1). Rather, the soul unites the body to itself in a way that it gives life and sets it free from sin to be eventually united to God. Along with the definitions of the human person, there are three main observations or principles that inform Augustine's philosophy of the human person in relation to God. These are self-awareness, participation, and immutability.

The first principle, discovered while reading the Platonists, is that of self-awareness (Confessions 7,10,16). Augustine's philosophy begins precisely with a reminder of the person, the self within, from which philosophy should begin. He says: "In the inward man dwells truth" (On the True Religion, 39,72). This is an irrefutable presence: the truth is offered to the mind with the characteristics of universality, necessity, immutability. The human mind is, therefore, connected with an intelligible and immutable reality. He writes:

"[The soul] is an intelligible nature and is also linked not only to intelligible things but even to immutable ones and, because it [i.e., the soul] has been 
ordered in such a way that, when it directs itself to those things to which it is linked or to its very self, it responds truthfully to them to the degree that it sees them" (Retractations $1,8,2 ; 1,4,4)$.

When speaking of the inner experience, Augustine brings in conversation the categories of being, thought, and love. These, he holds, are three forms in which the riches of one's spirit unfold. Every person who perceives is simultaneously making a reflection that concerns his or her being, thinking and loving. According to Augustine, three serious mistakes ought to be discarded or addressed. These are scepticism, materialism, and subjectivism. These are overcome by the light of intelligible truth. He says that if one is not sure of what Augustine is saying or has doubts about whether it is true, one can at least be sure that one has no doubt about having doubts. He explains that one ought to ask, where does this certainty come from? It comes from "the true light," which cannot be seen by human eyes (True Religion 39,73). With regard to this, in the Soliloquies, Augustine refers to the existence of God demonstrated in the way of truth, the spirituality of the soul, and the proof of its immortality (Soliloquies 2,13,24).

The second principle is that of participation. Augustine explains that everything that exists receives its essence from God, in whom each can participate. This is also applies to the human person. Given this premise, $\mathrm{Au}-$ gustinian thought unfolds majestically and fruitfully according to a threefold order, which is constituted by being, truth, and the good. In fact, Augustine likes to think of God as Being, as Truth, and as Love. In other words, God is the author of being, of truth, and of love. The full formula which expresses this doctrine is found in the City of God: "God is the cause of the created universe, the light of truth to know each other, a source of happiness to be achieved" (City of God 8,10,2). In God, in fact, there are "the principle of being, the truth of knowledge and the joy of living" (City of God 8,9). This concept embraces the whole of philosophy and determines the division between natural philosophy, the rational, and the moral; therein lies the foundation, which has its origins in the doctrine of creation, enlightenment, and bliss (City of God 2,7; 8,4). 
The third principle is that of immutability. Its importance lies in that it establishes and clarifies the other two principles of interiority and participation, showing the deepest metaphysical roots. For the Platonists, both God and the truth were immutable. Augustine accepts the principle, but is still not convinced about its conclusion. Augustine explains that from this immutability one can derive the other divine attributes and achieve the highest notion of God who is immutable because he excludes all composition (The Trinity 15,5,8). The same is said of the human person. Its relationship implies a sharing in the truth and in God himself who is immutable. In conclusion, these three principles shed light on the mystery of the human person in as much as he or she receives its essence and life from God.

\section{Conclusion}

Augustine emerges as an interesting figure who, like other ancient thinkers, reflects on the human person. His reflections are both philosophical and theological. He is initially inspired by Mani and claims that the human person has two substances: the soul and the body, opposed as light and darkness, good and evil. However, he moves away from such position until he discovers that Plato's idea of the body, as the prison of the soul, is equally not plausible. This leads him to an inward turn through which he discovers the nature and meaning of being human, particularly in the light of God. After analysing Augustine's principle of interiority, his Socratic and Aristotelian roots and presenting his thought, this research paper concludes with four main ideas concerning the human person.

First, Augustine emphasises that "man is a rational substance consisting of soul and body" (The Trinity 15,7,11). This view is shared by the Neoplatonists who also saw the human being as a rational substance consisting of soul and body (Plotinus, Treatise 1.1 and Porphyry's definition of the human being as a mortal rational animal in the Isagoge). What is important for the Neoplatonists is the soul (psyché), rather than the human being (anthropos). In Neoplatonic ethics, one should detach his or her soul from 
his or her body, and live the life of the soul, not of the human being (which is an inferior composite). For Augustine, however, the body and the soul are united in one person. The body is an essential part of man and woman. Their union is so deep, he claims that it even helps us to understand the mystery of the Incarnation. In other words, Augustine clearly states that it is false to say that man is simply the mind or simply the body (Sermon $154,3,11)$. The body and the soul require each other. He affirms that both the soul and the body were created by God and the soul came into existence once the body was created.

Secondly, Augustine prefers moving from an abstract understanding of the human person to a more grounded (historical) understanding. This means that the definition of the human as a "rational, mortal animal", indicating a metaphysical structure must be contextualized in history and in practical terms (The Trinity 15,7,11; Cicero, Academica Priora 2,7,21). Augustine explains that the "magna quaestio" about the nature of a human person must equally be valued in terms of tranquillity of order (tranqillitas ordinis) and virtue as the order of love (ordo amoris). So, in contrast to the modern era where the human person has been described in terms of "useless passion" (Sartre), "absurdity" (Camus), and "libido" (Freud), Augustine insists that the human person is "passion, power, strength, [and] love" (Piccolomini 2002, 286). The human person is alive and dynamic.

Thirdly, influenced by Aristotle, Augustine discusses the human person as an indissoluble unity of soul and body. The human person consists of a whole being: mind and will, thought and affection, sense and heart, nature and the supernatural. The Confessions - from beginning to end - are an unquestionable evidence to this. This brings Augustine to speak of the human person in relationship. In philosophical terms, the human person is concerned about that unity wherein the "I" is related to the things that the mind learns, the love that is wanted, and the freedom that is chosen. The human person is of a "primary value" since only God enjoys "absolute" value (Piccolomini 2002, 287.). In this regard, one could speak of the greatness and misery of the human person. Thus, while humans can be compared to "parched grass", they are capax Dei and tend towards the supreme good 
(Confessions 11,2,3). To Augustine, the greatness of the human person lies in the wonder of the unity between the body and the soul (Vannier 1990, 349-371).

Lastly, Augustine knows that the human person comes through an entering into self. To Augustine, the process to know the human person entails the ability to transcend the realm that lies exterior to him or her. What is important here are the presence of the self and a trend towards interiority. Overcoming the dangers of subjectivism and solipsism, Augustine presents a method that propagates a return to oneself. Knowledge should not be derived from the external world, but rather from the presence of the self to itself. It is there that the self encounters God. It is this method, according to Augustine that gives meaning to the human person. Augustine's method involves a simple turn in oneself in order to penetrate the deepest core of reason and one's conscience. Ramiro Flórez identifies this as a "meditation" or a "reflection" of self-awareness in contrast to a "remembering" (Flórez 1954, 552). He says:

Man does not know himself. Now, for acquiring this self-knowledge, he needs a constant habit of withdrawing from things of the senses and of concentrating his thought within himself, and holding it there (On Order 1,1,3).

This reflection starts from a soliloquy a person has by itself and ends in a dialogue of a seeker in front of God: "Deliberations alone with myself in your sight” (Confessions 9,4,7). It becomes clear that for Augustine, this reflection does not involve some kind of a strict rational exercise, but rather one of introversion and transcendence. He says: "Do not go abroad. Return within yourself. In the inward man dwells truth. If you find that you are by nature mutable, transcend yourself" (Of True Religion 39,72). This brings us to a closure with no better words expressed by Rowan Williams (1950-) on Augustine's intellectual legacy in view of interiority:

To be human is to desire, to be drawn and moulded by extra-rational, even extra-mental, attractive forces. Augustine's greatest legacy to Christian spirituality is the affirmation that the life of grace can include not only moral struggle and 
spiritual darkness, but also an awareness of the radically conditioned character of human behaviour - marked as we are in ways unknown to us by childhood experience, historical and social structures, and many more facts of which Augustine himself could not have been consciously aware of, but to which our own age is especially sensitive. If human behaviour is such, the "creation" of a life realising the purposes of God, the transformation of image into likeness, is not impossible, but does take on a different quality. The emphasis must be not upon achievement but upon attitude. What holds a life together is simply the trust - or faith - that the eyes and the heart are turned towards truth, and that God accepts such a life without condition, looking on the will rather than merely the deed. God asks not for heroes but for lovers; not for moral athletes but for men and women aware of their need for acceptance, ready to find their selfhood in the longing for communion with an eternal “other” (Williams 1990, 88-89).

To finish, Augustine refers to four elements to answer the question "What makes us human?" These are the nature of the human being, its interiority, its exteriority and the self. Augustine emphasises the unity of the body and the soul in one person, the disposition to enter into self and to transcend the external human condition, the sensibleness of the human actions and the process to take an inward turn to recognise the self as one whole being.

\section{References}

\section{Primary Sources}

Augustine. 1948. On Order [De ordine], trans. Robert P. Russell, Fathers of the Church 5, 239-332. New York: Catholic University of America Press. Augustine. 2000. Soliloquies [Soliloquia]. Hyde Park, New York: New City Press. Augustine. 1947. The Immortality of the Soul [De immortalitate animae], trans. Ludwig Schopp. New York: Catholic University of America Press.

Augustine. 1947. The Measure of the Soul [De quantitate animae], trans. John J. McMahon, Fathers of the Church 2, 59-149. New York: Catholic University of America Press.

Augustine. 2005. On Christian Belief (De Vera Religione), edited by Michael Ramsey, trans. Edmund Hill, The Works of St Augustine I/8, 13-104. Hyde Park, New York: New City Press. 
Augustine. 1997. Confessions [Confessiones], edited by John E. Rotelle, trans. Maria

Boulding, The Works of St Augustine I/1. Hyde Park, New York: New City Press. Augustine. 1991. The Trinity [De Trinitate] edited by John E. Rotelle, trans. Edmund Hill, The Works of St Augustine I/5. Hyde Park, New York: New City Press.

Augustine. 1972. The City of God [De civitate Dei], trans. Henry Bettenson, London: Pelican Classics.

Augustine. 1996. On Christian Instruction [De doctrina Christiana], edited by John

E. Rotelle, trans. Edmund Hill, The Works of St Augustine I/11. Hyde Park, New York: New City Press.

Augustine. 2000-2004. Exposition of the Psalms [Enarrationes in Psalmos] edited

by John E. Rotelle/Boniface Ramsey, trans. Maria Boulding, The Works of St Augustine I/15-20. Hyde Park, New York: New City Press.

Augustine. 2005. Letters [Epistulae], edited by John E. Rotelle/Boniface Ramsey, trans. Roland Teske, The Works of St Augustine II/1-4. Hyde Park, New York: New City Press.

Augustine. 1990-1997. Sermons [Sermones], edited by John E. Rotelle, trans. Edmund Hill, The Works of St Augustine III/1-11. Hyde Park, New York: New City Press. Augustine. 2006. The Catholic Way of Life and the Manichean Way of Life [De moribus Ecclesiae catholicae et de moribus Manichaeorum], edited by Boniface Ramsey, The Works of St Augustine I/19. Hyde Park, New York: New City Press. Augustine. 2010. Revisions [Retractationes], edited by Roland Teske, trans. Boniface Ramsey, The Works of St Augustine III/14. Hyde Park, New York: New City Press.

\section{Secondary Sources}

Alici, Luigi., and Remo Piccolomini, Antonio Pieretti. 2001. Interiorità e persona. Agostino nella filosofia del novecento 2. Roma: Città Nuova.

Alici, Luigi. 1991. “Interiorità e speranza.” In Interiorità e intenzionalità nel De civitate Dei di Sant'Agostino. Atti delle III. Seminario Internazionale del centro di Studi Agostiniani di Perugia, edited by Remo Piccolomini, 55-73. Roma: Institutum Patristicum Augustinianum.

Battenhouse, Roy W. 1956. A Companion to the Study of St Augustine, New York: Oxford University Press.

Bermon, Emmanuel. 1986-1994. “Persona.” In Augustinus-Lexikon, 4, edited by Cornelius Mayer, Karl Heinz Chelius, 693-700. Basel: Schwabe Verlag.

Bogliolo, Luigi. 1956. “Significato e attualità dell'interiorità agostiniana.” In S. Agostino e le grandi correnti della filosofia contemporanea. Atti del Congresso 
Italiano di Filosofia Agostiniana, Roma 20-23 ottobre 1954, 319-26. Tolentino: Edizioni Agostiniane.

Bonafede, Giulio. 1954. “Interiorità e immanenza.” In S. Agostino e le grandi correnti della filosofia contemporanea, 312-8. Roma: La Civiltà cattolica.

Campelo, Moisés María. 1981. Conocer y pensar: Introducción a la noética agustiniana. Valladolid: Ed. Estudio Agustiniano.

Cary, Philip. 2003. Augustine's Invention of the Inner Self: The Legacy of a Christian Platonist. Oxford: University Press.

Cary, Phillip. 1999. “Skeptics, Skepticism.” In Augustine through the Ages. An Encyclopedia, edited by Allan D. Fitzgerald, 802-3. Grand Rapids, Michigan Cambridge: Eerdmans.

Cary, Phillip. 2003. “Book Seven: Inner Vision as the Goal of Augustine's Life.” In A Reader's Companion to Augustine's Confessions, edited by Kim Paffenroth, Robert P. Kennedy, 107-26. Louisville, London: Westminster John Knox Press. Cary, Phillip. 1999. “Interiority.” In Augustine through the Ages. An Encyclopedia, edited by Allan D. Fitzgerald, 454-6. Grand Rapids, Michigan - Cambridge: Eerdmans.

Cary, Phillip. 1999. “Varro.” In Augustine through the Ages. An Encyclopedia, edited by Allan D. Fitzgerald, 863-4. Grand Rapids, Michigan - Cambridge: Eerdmans. Cary, Phillip. 2008. Inner Grace: Augustine in the Traditions of Plato and Paul. Oxford: University Press.

Ceriotti, Giancarlo. 2004. “Il linguaggio dell'interiorità.” Agostino d'Ippona. Presenza e pensiero. La scoperta dell'interiorità, edited by Alfredo Marini, 41-63. Milano: F. Angeli.

Ciacon, Carlo. 1964. Interiorità e metafisica: Aristotele, Plotino, Agostino, Bonaventura, Tommaso, Rosmini. Bologna: Zanichelli.

Cipriani, Nello. 1996. "L'influsso di Varrone sul pensiero antropologico e morale nei primi scritti di S. Agostino.” Studia Ephemeridis Augustinianum 53:369-400. Costantini, Elio. 1987. "La ricerca filosofica come processo d'interiorità in S. Agostino e in Husserl." In Congresso Internazionale su S. Agostino nel XVI centenario della conversione, Roma, 15-20 settembre 1986. Atti 2, 483-91. Roma: Institutum Patristicum Augustinianum.

Cotta, Sergio. 1991. "La pace tra interiorità e intenzionalità: la posizione agostiniana." In Interiorità e intenzionalità nel De civitate Dei di Sant'Agostino. Atti delle III. Seminario Internazionale del centro di Studi Agostiniani di Perugia, edited by Remo Piccolomini, 43-54. Roma: Institutum Patristicum Augustinianum. Fabro, Cornelio. 1958. “Coscienza e autocoscienza dell'anima.” Doctor Communis 11:97-123. 
Flórez, Ramiro. 1952. "La Inquietud religiosa y las condiciones de la paz personal en el pensamiento de San Agustín.” In Actas del XXXV Congreso Eucarístico Internacional, Sesiones de Estudio. 1:265-78. Barcelona: s.n.

Flórez, Ramiro. 1954. "Puntos para una antropología agustiniana.” In Augustinus magister: Congrès International Augustinien, Paris, 21-24 septembre 1954, 1:551-57. Paris: Études augustiniennes.

Flórez, Ramiro. 1958. Las dos dimensiones del hombre agustiniano. Madrid: Ediciones Religión y Cultura.

Giacon, Carlo. 1964. Interiorità e metafisica: Aristotele, Plotino, Agostino, Bonaventura, Tommaso, Bologna: Zanichelli.

Gilson, Etienne. 1936. The Spirit of Medieval Philosophy, New York: Scribner's.

Henry, Paul. 1937. “Augustine and Plotinus.” Journal of Theological Studies 38:1-23.

Henry, Paul. 1938. La vision d'Ostie. Sa place dans la Vie et l'Eeuvre de saint Augustin.

Paris: Vrin.

Henry, Paul. 1934. Plotin et l'Occident. Louvain: Spicilegium.

Henry, Paul. 1960. Saint Augustine on Personality, New York: Macmillan.

Labriolle, Pierre Champagne de. 1948. “Introduction.” In De Immortalitate Animae, Euvre de Saint Augustin, V. Dialogues Philosophiques, vol. 2: Dieu et l'Ame, edited by Idem, 165-7. Paris: Desclée de Brouwer.

O’Daly, Gerard. 1987. Augustine’s Philosophy of Mind, London: Duckworth.

O’Donnell, James J. 2001. “Augustine: His Time and Lives.” In The Cambridge Companion to Augustine, edited by Eleonore Stump, Norman Kretzmann, 8-25. Cambridge: University Press.

Piccolomini, Remo. 2002. “L'interiorità e il ricupero dell'uomo.” Rivista di Scienze Religiose 16:279-90.

Ramsey, Boniface. 2000. “Introduction.” In Soliloquies, edited by Boniface Ramsey, Augustine, 7-14. New York: New City, Hyde Park.

Sanabria, José Rubén. 1987. “Agustín de Hipona, filósofo de la interioridad y del amor.” Revista de filosofía 20:118-56.

Vannier, Marie-Anne. 1990. “Saint Augustin et la creation.” In Collectanea Augustiniana. Mélanges T.J. Van Bavel, edited by Bernard Bruning, Mathijs Lamberigts, Jozef Van Houtem, 1:349-71. Leuven: Leuven University Press.

Williams, Daniel D. 1956. “The Significance of St Augustine Today.” In A Companion to the Study of St Augustine, edited by Roy W. Battenhouse, 3-14. New York Oxford: University Press.

Williams, Rowan. 1990. The Wound of Knowledge. Christian Spirituality from the New Testament to St John of the Cross, London: Cowley Publications. 